\title{
ERADICATION PROGRAM OF FOOT AND MOUTH DISEASE IN THE STATE OF SÃO PAULO: EVALUATION OF OFFICIAL DATA OBTAINED BETWEEN 1997-2012
}

\section{PROGRAMA DE ERRADICAÇÃO DE FEBRE AFTOSA NO ESTADO DE SÃO PAULO: AVALIAÇÃO DE DADOS OFICIAIS OBTIDOS ENTRE 1997-2012}

\author{
Acácio Romualdo Assoni Rodrigues ${ }^{1}$ \\ Luís Guilherme de Oliveira $2^{2^{*}}$ \\ Igor Renan Honorato Gatto ${ }^{2}$ \\ Henrique Meiroz de Souza Almeida² \\ Gabriel Augusto Marques Rossi² \\ Marina Lopes Mechler² \\ Samir Issa Samara²
}

${ }^{1}$ Secretaria de Agricultura e Abastecimento de São Paulo, São José do Rio Preto, SP, Brazil.

${ }^{2}$ Faculdade de Ciências Agrárias e Veterinárias da Universidade Estadual Paulista, Jaboticabal, SP, Brazil.

*Corresponding author- luis.guilherme@fcav.unesp.br

\begin{abstract}
Foot and mouth disease (FMD), a highly contagious disease that affects cloven-hoofed animals, is known by the economic losses it causes in farms and in regions where it is endemic. The State of São Paulo has not recorded FMD outbreaks since 1996. Based on official data from 1997 to 2012, this study organized, analyzed, and confronted the following information with the current literature: a) the FMD vaccination rates from 1997 to 2012 in São Paulo; b) the results of the official monitoring designed to demonstrate the effectiveness of vaccination against FMD; c) the passive surveillance procedures and compliance with reports of suspected vesicular disease in the State of São Paulo; d) the results of the official monitoring designed to demonstrate the absence of viral circulation in the State of São Paulo; e) the relation between the preventive measures adopted by the veterinarian official service with the challenge of FMD outbreaks in other neighboring states. Finally, the description of the free area without vaccination implementation prospects for the State of São Paulo, classification granted by the World Organization for Animal Health (OIE). The data analysis showed that sanitary measures, strategies, and the methodology to assess the efficacy of the FMD eradication program in the State of São Paulo were efficient. Even though the data suggest that the state is able to upgrade to a FMD free area without vaccination, some aspects should be taken into account, such as the structure of the state's Official Veterinary Service, disease control programs in states epidemiologically related with São Paulo and the commitment of the whole supply chain with surveillance and eradication of FMD.
\end{abstract}


Keywords: animal health program; cloven-hoofed animals; vaccination; vesicular disease.

\section{Resumo}

A Febre Aftosa (FA), doença altamente contagiosa que afeta os animais biungulados, é reconhecida pelos prejuízos econômicos nas propriedades e nas regiões onde é endêmica. O Estado de São Paulo não registra focos de FA desde 1996. A partir de dados oficiais obtidos de 1997 a 2012, este estudo organizou, analisou e confrontou as seguintes informações com a literatura pertinente: a) as taxas de vacinação contra FA de 1997 a 2012 no Estado de São Paulo; b) os resultados do monitoramento oficial delineado para demonstrar a eficiência da vacinação contra a FA; c) os procedimentos de vigilância passiva e de atendimento às notificações de suspeitas de doenças vesiculares no Estado de São Paulo; d) os resultados do monitoramento oficial delineado para demonstrar a ausência de circulação viral no Estado de São Paulo; e) a relação entre as medidas preventivas adotadas pelo serviço veterinário oficial diante de focos de FA em outros Estados limítrofes. Finalmente, foram descritas as perspectivas de implementação de área livre sem vacinação para o Estado de São Paulo, classificação outorgada pela Organização Mundial de Saúde Animal (OIE). A análise dos dados demonstrou que as medidas, estratégias e métodos de avaliação do programa de erradicação da FA aplicadas no Estado São Paulo foram eficientes para o objetivo a que se propõem. Apesar dos pontos analisados apresentarem-se favoráveis à mudança de classificação do Estado de São Paulo para área livre de FA sem vacinação, outros aspectos deverão ser verificados, como a estrutura do Serviço Veterinário Oficial estadual, o nível de controle de Estados com vínculo epidemiológico com o Estado de São Paulo e o comprometimento de toda a cadeia produtiva com a vigilância da FA.

Palavras-chave: animais biungulados; doença vesicular; programa sanitário animal; vacinação.

Received on April 19 $9^{\text {th }}, 2016$

Accepted on February $3^{\text {rd }}, 2017$

\section{Introduction}

The number of cattle herds and producers has reduced from 1997 to 2012 due to the evolution of the sugar cane production and the reduction of grazing areas; however, the livestock industry of São Paulo State still has high national economic importance. Foot and Mouth Disease (FMD) is known by the economic losses it causes in all livestock production chain. This highly contagious disease, when endemic, is the major constraint of a country or region to international trade of animals and animal products ${ }^{(1)}$. FMD-free countries receive better profit for animals and products.

São Paulo State holds the internationally recognized status of FMD-free region with vaccination, granted by OIE since 2000 as a result of the measures taken in 1992 to eradicate the disease. During the years 2005/2006, the state had its free status suspended by the OIE due to outbreaks in neighboring states; however, after the outbreak control, the free status was granted again and it remains until nowadays ${ }^{(2)}$. By developing the program of FMD eradication, the Official Veterinary Service (OVS) of São Paulo intends to maintain the current condition, aiming at achieving free 
status without vaccination.

However, the data obtained by the OVS, State Department of Agriculture and Food Supply of São Paulo (SAA-SP) related to the management of FMD had only been analyzed and linked in official reports submitted to higher instances, and the World Organisation for Animal Health (OIE) had no scientific analysis. Therefore, this study aimed to analyze the FMD vaccination rates from 19972012 in São Paulo, the official monitoring of vaccination efficiency, the absence of viral circulation of FMD virus (FMDV), the procedures of passive surveillance and prevention of FMDV entrance in the state, comparing the results with the literature. This information can prove the effectiveness of the disease eradication program in the State of São Paulo.

\section{Materials and methods}

This study was conducted in São Paulo State, Brazil. This State has an important animal population of approximately 10.3 million bovines, 1.2 million swine ${ }^{(3)}, 0.5$ million sheep, and 0.06 million goats, and has a total area of 248,222 $\mathrm{km}^{2(4)}$. São Paulo is bordered by Minas Gerais State (north), Paraná State (south), Mato Grosso do Sul State (west), Rio de Janeiro State and Atlantic Ocean (east) (Figure 1).

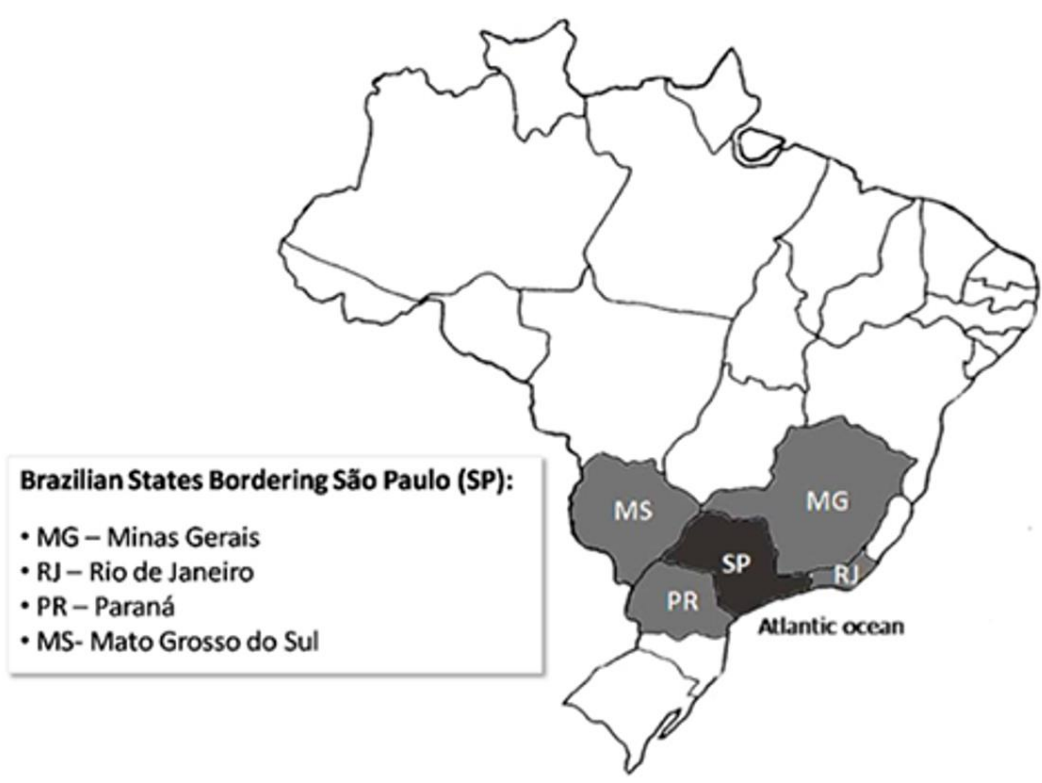

Figure1. Map of Brazil indicating São Paulo State and bordering areas.

The criteria used in the analysis of these rates are the standards and state regulations, especially SAA Resolution 01 of Janyary $17^{\text {th }} 2002^{(5)}$, standards and federal regulations, especially the Normative Instruction of the Ministry of Agriculture, Livestock, and Supply (MAPA) No 44 of October $2^{\text {nd }}, 2007^{(6)}$, and international norms and regulations, such as the Hemispheric Program for the Eradication of Foot and Mouth Disease (PHEFA) ${ }^{(7)}$, which aims to eradicate FMD in South 
America through its Action Plan 2011-2020.

The Normative Instruction of the Ministry of Agriculture, Livestock, and Supply (MAPA) No 44 of October $2^{\text {nd }}, 2007^{(6)}$ regulates the main items related to the control and eradication of FMD. The National Program for the Eradication and Prevention of Foot and Mouth Disease (PNEFA) recommends vaccination should be performed only in cattle and buffaloes, being prohibited in swine, goats, sheep, and other susceptible species, except in special situations.

Vaccination strategies against FMD are set by the OVS, according to the epidemiological situation of the Unit of the Federation, district, or other geographical areas. The FMD current vaccination schedule used in São Paulo was defined by SAA 74 from November $27^{\text {th }}, 2009^{(8)}$, which determined the vaccination against FMD of all cattle and buffalo aged up to 24 months in May and of the entire herd in November of each year, with oil adjuvant vaccines approved by MAPA and indicated by the SAA/SP.

According to the SAA Resolution 01 from Janyary $17^{\text {th }}, 2002^{(5)}$ to implement the vaccination, the farmer can only acquire the vaccine from registered resellers in OVS. This vaccine should be transported and stored at 2 to $8{ }^{\circ} \mathrm{C}$, until the moment of application. The vaccination must be performed as hygienically as possible; materials should be disinfected without chemicals. The handling of animals should be rational, avoiding excessive shaking and following the standards of animal welfare ${ }^{(5)}$.

The records of the properties, such as declarations of vaccinations and the records of animal transportation, were initially made in manual filling forms. SAA / SP implemented, through SAA Resolution $79^{(9)}$ from December10 ${ }^{\text {th }}$, 2012, the Management System of Animal and Vegetable Defense (GEDAVE). Through GEDAVE, the external user (such as farmers, veterinarians, and vaccine resellers) can have, upon request and password, access to their records for data entry and issuing documents, as waybills and vaccination electronic certificates, accelerating the attendance and facilitating the control by official agencies.

The official monitoring of data that demonstrates the effectiveness of vaccination against FMD in São Paulo follows the procedures outlined by MAPA and executed by the OVS. The results are recorded in the database of the OVS.

We evaluated the monitoring results of 2005, 2008, and 2010. Each monitoring has its procedures described in a proper manual ${ }^{(10-12)}$. The monitoring to detect the effectiveness of FMD vaccine conducted in 2010 presents the following main points: 1) the samples are distributed according to age groups (6-12 months and 13-24 months) and size of herds (up to 50 cattle and more than 50 cattle); 2) using the liquid-phase blocking enzyme-linked immunosorbent assay (LPB-ELISA) manufactured by PANAFTOSA- ("Centro Panamericano de Fiebre Aftosa") to detect specific antibodies against the viral capsid proteins (structural proteins) of genotypes $\mathrm{O}, \mathrm{A}$, and $\mathrm{C} ; 3$ ) the confidence level of the study was predetermined by $95 \%$, which ensured that the results obtained for the sample population had this probability of being representative of the target population.

The monitoring of the vaccination efficiency conducted in 2008 was done separately for ERAS properties, which are rural establishments approved in SISBOV (eligible for export to the European Union) and non-ERAS properties; and in the other monitoring the sampling did not use specific criteria to choose properties.

The assistance to reports of suspected vesicular diseases was initially performed by local veterinary 
units, which are units of service that have at least one official veterinarian. In case of suspicion, the GEASE (Special Group of Attention to Suspected Disease Emergency) is triggered. GEASE role and composition is established by joint SAA Resolution / MAPA No 1 from March $7^{\text {th }}, 2006^{(13)}$. The description of the attendance was obtained through the records in SiVCont (Continental Epidemiological Surveillance System), where reports of vesicular diseases in South America are recorded $^{(14)}$.

We evaluated the official monitoring of FMD viral circulation in São Paulo throughout 1999, 2001, 2002, 2005, 2006, 2008, and 2010. The diagnostic method was the presence of antibodies against non-capsidal proteins of Foot and Mouth Disease Virus (FMDV), complemented by clinical inspection, epidemiological evaluation, harvesting, and paired samples of esophageal-pharyngeal fluid (EPF) for viral isolation.

The immunodiffusion test on Agar Gel (AGID) was used to detect antibodies anti-VIA antigen, whose role in seroepidemiological surveys is to monitor hosts, mainly sheep and goats. I-ELISA was used to test the material of the $1^{\text {st }}$ crop of cattle in surveys in 2005, 2006, 2008, and 2010, and it consisted in the enzyme immunoassay that allows in vitro detection of antibodies against noncapsidal protein $3 \mathrm{ABC}$ of FMDV, which is used as an indicative mark of exposure to live virus ${ }^{(15)}$.

The EITB was used to test the material of the $2^{\text {nd }}$ crop of positive cattle in the $1^{\text {st }}$ crop in all surveys, and it has also been used to test the $1^{\text {st }}$ crop material in the surveys of 1999, 2001, and 2002. This test consists in performing the immunoassay of in vitro detection of antibodies against the noncapsidal proteins $3 \mathrm{ABC}, 3 \mathrm{D}, 2 \mathrm{C}, 3 \mathrm{~B}$, and $3 \mathrm{~A}$ of $\mathrm{FMDV}$, which is used as an indicative mark of exposure to live virus ${ }^{(16)}$.

As non-capsidal proteins of FMDV are highly conserved among different serotypes, both EITB and I-ELISA could be applied to search hosts of any serotype of the FMDV. Its use is only recommended in the active surveillance of FMD in populations up to 2 years old. Therefore, it can be used regardless of the vaccination condition ${ }^{(16)}$. The probang technique was used to harvest EPF.

OIE records were checked ${ }^{(17)}$ for identification of outbreaks in Brazil regarding its spatial location and the standards published by the OVS to examine the measures taken. We evaluated the epidemiological surveillance procedures performed in order to prevent the FMDV entrance in São Paulo, and consequently to maintain the status of FMD-free with vaccination.

\section{Results and discussion}

The PHEFA 2011-2020(7), which aims at FMD eradication in South America, proposes a FMD-free zone with vaccination.

The vaccination coverage expected results are $90.0 \%$ in the first year and $95.0 \%$ from the fifth year. The Normative Instruction No. 44 from October $2^{\text {nd }}, 2007^{(6)}$ determines the biannual vaccination of cattle and buffaloes up to 24 months and the annual vaccination for all ages could only be adopted in regions where the registration of farms is consolidated, as well as the carry-out of biannual vaccination for at least two consecutive years observing global vaccination rates greater than $80.0 \%$. 
By the organizational analysis of these data, we observed the vaccination rates in São Paulo, concerning the stages of November, in the period from 1997 to 2012, are above the minimum standards of PHEFA 2011-2020 ${ }^{(15)}$, which are $95.0 \%$ vaccination for regions or countries that wish to change the FMD-free with vaccination rating to FMD-free without vaccination. Vaccination rates in November from 1997 to 2012 are shown in Figure 2.

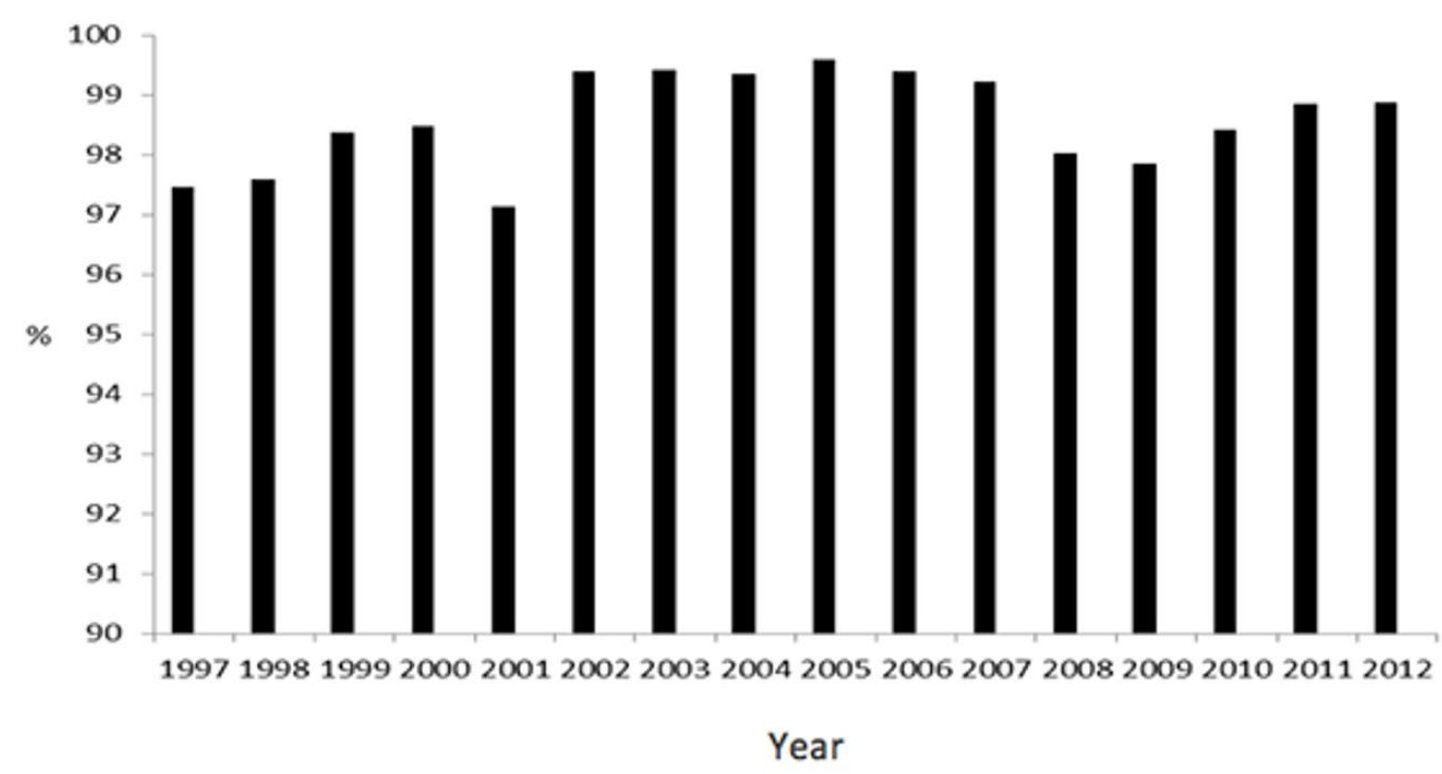

Data source: CDA/SAA/SP

Figure 2. Graph of the percentage of bovine declared by the owners as vaccinated against FMD in the stages of November in São Paulo, between 1997-2012.

Table 1 displays the results of serological surveys of bovines tested with ELISA-CFL for determining the FMD vaccine efficiency in São Paulo. These surveys were conducted in 2005, 2008, and 2010, and the prevalence values obtained were firstly corrected according to sensitivity and specificity values, which ranged from $87 \%$ to $100 \%$.

The Health Code for Terrestrial Animals ${ }^{(17)}$ recommends that at least $80.0 \%$ of the vaccinated animals have protective immunity in areas free of FMD with vaccination. The parameters of the PHEFA 2011-2020 results ${ }^{(14)}$ are immunity from $85.0 \%$ and $90.0 \%$, respectively, for the second last and the last year of change from FMD-free with vaccination classification to free of FMD without vaccination. The level of protection reported in the three surveys conducted in São Paulo reached over $80 \%$.

Table 2 shows the number of notifications recorded as vesicular syndromes by the OVS of São Paulo in SiVCont ${ }^{(14)}$. No focus of FMD was identified in any of the attendances. This system has notifications records from the year 2005 .

These data revealed that during the period from 2005 to 2011 notifications were made, mostly in cases of cowpox, as well as a case of malignant catarrhal fever, a case of vesicular stomatitis and five unconfirmed cases of suspected vesicular disease. The amount of vesicular diseases notifications can be considered low, taking into account the period between 2005 and 2011, and the number of 139,767 existing herds in São Paulo in 2011. 
Table 1. Relation of the serologic inquiries to determine the FMD vaccine efficiency in São Paulo in 2005, 2008, and 2010

\begin{tabular}{|c|c|c|c|c|c|}
\hline Year of survey & $\begin{array}{l}\text { FMDV } \\
\text { Type }\end{array}$ & $\begin{array}{c}\text { No of } \\
\text { participating } \\
\text { properties }\end{array}$ & $\begin{array}{c}\text { No Cattle sampled / } \\
\text { No protected cattle } \\
\text { (Ab found in LPB- } \\
\text { ELISA, limit titer } \\
\mathbf{2 . 1 0} \text { ) }\end{array}$ & $\begin{array}{l}\text { Apparent / } \\
\text { Observed } \\
\text { Prevalence }\end{array}$ & $\begin{array}{l}\text { Corrected }^{*} / \text { True } \\
\text { prevalence }\end{array}$ \\
\hline 2005 & $A$ & 106 & $1001 / 838$ & $84 \%$ & $99 \%(98.17 \%-99.45 \%)$ \\
\hline 2008 ERAS $^{b}$ & $O$ & 3 & $168 / 168$ & $100 \%$ & $100 \%(97.76 \%-100 \%)$ \\
\hline $\begin{array}{l}2008 \text { non- } \\
\text { ERAS }^{b}\end{array}$ & $O$ & 49 & $194 / 158$ & $81 \%$ & $97 \%(93.54 \%-98.63 \%)$ \\
\hline 2010 & $\begin{array}{l}O \text { and } \\
A\end{array}$ & 37 & $202 / 178$ & $88 \%$ & $88 \%$ (82.91\%-91.91\%) \\
\hline 2010 & $\begin{array}{l}O \text { and } \\
C\end{array}$ & 37 & $202 / 176$ & $87 \%$ & $87 \%(81.79 \%-91.1 \%)$ \\
\hline 2010 & $\begin{array}{l}A \text { and } \\
C\end{array}$ & 37 & $202 / 180$ & $89 \%$ & $96 \%(92.33 \%-97.95 \%)$ \\
\hline
\end{tabular}

-The apparent prevalence / observed was corrected to true prevalence / corrected due to the sensitivity and specificity of the test.

bERAS propertics: farms approved in SISBOV, with authorization to export beef to the EU; non-ERAS properties: farms without the authorization for exporting beef to the European Union.

Data source: BRASIL(10-12)

Table 2. Number of sanitary events reported as suspected vesicular syndrome in São Paulo, between the years 2005 and 2011

\begin{tabular}{cccccc}
\hline Year & Species & \multicolumn{4}{c}{ Diagnostic } \\
& & Negative VE & $\begin{array}{c}\text { Malignant } \\
\text { catarrhal fever }\end{array}$ & $\begin{array}{c}\text { Vesicular } \\
\text { Estomatitis }\end{array}$ & Cowpox \\
\hline 2005 & Equine & - & - & 1 & - \\
2005 & Bovine & 1 & - & - & 1 \\
2006 & Bovine & - & - & - & 2 \\
2007 & Bovine & 2 & 1 & - & 1 \\
2008 & Bovine & - & - & - & 21 \\
2009 & Bovine & 2 & - & - & 9 \\
2010 & Bovine & - & - & - & 2 \\
2011 & Bovine & - & - & - & 1 \\
\hline
\end{tabular}

The FMD is a compulsory notifiable disease by any citizen, made immediately to the official service (Instruction No 50, September $\left.24^{\text {th }}, 2013\right)^{(18)}$. After a laboratory negative confirmation of 
FMD, the property remains interdicted and measures to contain outbreaks of diseases similar to the FMD are taken, respecting the epidemiological characteristics of each disease. The liberation of the properties occurs, for example, in the case of vesicular stomatitis, 21 days after the cure of the last animal $^{(19)}$.

The relatively low number of vesicular disease notifications may indicate that farmers are not aware of these disorders, or do not know they need to notify. The low number of reports of suspected vesicular disease depends on health education of farmers and professionals involved in bovine production and capillarity of the OVS.

Active surveillance for foot-and-mouth disease in other species (swine, sheep, and goats) occurs mainly during vaccination campaigns, through official surveillance of some farms ${ }^{(6)}$. This action is apparently insufficient because it reaches a reduced number of farms. It is worth remembering that swine is a specie that acts as an excellent sentinel when infected by FMD virus ${ }^{(20)}$, so they should be inspected routinely.

It should be noted that passive surveillance activities are very rare, and it is possible to suggest changes in animal health education strategies. More training actions about foreign animal diseases should be done for practitioners and veterinary students, as well as the notification form through should be facilitated by App technology.

The Health Code for Terrestrial Animals ${ }^{(17)}$ recommends that in order for a country or zone to be recognized as FMD-free, viral circulation should not have been detected in the last 12 months. In all stages of the surveys, the selection of municipalities and properties were responsibility of MAPA, which used the database of animal movement and properties, made available by the state veterinary services. The selection of the animals within each batch was, in turn, responsibility of the collection team, who used a random sampling method. Table 3 displays the inquiries for detection of FMD viral circulation in São Paulo, from 1999 to 2010. Official monitoring of data demonstrating the effectiveness of FMD vaccination in the state of São Paulo follows the procedures outlined by MAPA and performed by CDA / SAA / SP. The results are recorded in the CDA / SAA / SP.

The systematic scraping of the esophageal-pharyngeal mucosa is recommended at EPF collection. This procedure is essential for the quality of the sample, since the major FMDV replication sites are the floor of the pharynx and the virus flows into the dorsal surface of the soft palate. In the positive animal, FMDV should be present in the epithelial cells that become detached from esophagealpharyngeal region with the presence of oral fluid, mucus, and food debris ${ }^{(19)}$.

EITB and I-ELISA-3ABC (97.2\% sensitivity and 98\% specificity) are performed to detect antibodies against FMDV non-capsidal proteins, which can be found in vaccinated animals and carriers of the virus. When animals that have received several doses of the vaccine present these antibodies, the confirmatory test is done by the isolation of the agent from the EPF. This procedure does not take into account the fact that some vaccine manufacturers laboratories already have purified ("clean") vaccines that do not stimulate the production of antibodies against non-capsidal proteins $^{(21)}$.

Described in the seven surveys, the tests did not evidence FMDV circulation in São Paulo. Surveys conducted in 1.172 properties, from 1999 to 2010, detected 186 animals reactive in EITB and Eliza $3 \mathrm{ABC}$ in the first assessment, 52 reactive in the EITB test in the second assessment made with the positive animals from the previous tests, whereas all these animals were negative in the 
confirmatory FMDV test isolation.

Table 3. Number of farms and tests from bovine material in surveys to detect the activity of the FMD virus in São Paulo, in the period from 1999 to 2010

\begin{tabular}{|c|c|c|c|c|c|}
\hline \multirow{3}{*}{$\begin{array}{l}\text { Year of } \\
\text { inquiry }\end{array}$} & \multirow[t]{3}{*}{ No of farms } & \multicolumn{3}{|c|}{ No of farms with positive animals } & \multirow{3}{*}{$\begin{array}{l}\text { No of farms with negative animals } \\
\text { by virus insulation, after the } \\
\text { gathering of EPF (probang) }\end{array}$} \\
\hline & & & $1^{\text {st }}$ test & $2^{\text {ed }}$ test & \\
\hline & & EITBa & ELISA3ABC ${ }^{b}$ & EITBa & \\
\hline 1999 & 444 & 65 & - & 5 & 5 \\
\hline 2001 & 3 & 0 & - & - & - \\
\hline 2002 & 35 & 22 & - & 4 & 4 \\
\hline 2005 & 60 & - & 18 & 8 & 8 \\
\hline 2006 & 456 & - & 45 & 3 & 3 \\
\hline 2008 & 114 & - & 29 & 29 & 29 \\
\hline 2010 & 60 & - & 7 & 3 & 3 \\
\hline
\end{tabular}

${ }^{2}$ The EITB test was used as a $1^{\text {st }}$ proof test in the inquiries from 1999, 2001, and 2002, and as $2^{\text {nd }}$ proof in all inquiries.

'The ELISA $3 \mathrm{ABC}$ was used as a 1s: assessment for cattle in the inquiries of 2005, 2006, 2008, and 2010.

EEPF: esophageal-pharyngeal fluid

Data source: CDA/SAA/SP e MAPA

The parameters recommend by PHEFA 2011-2020(7) state the classification change from "FMDfree area with vaccination" to "free area without vaccination" occurs in regions without occurrence of FMD in the last 10 years. São Paulo had its last FMD outbreak in $1996^{(1)}$.

Table 4 displays the FMD outbreaks occurred in the states of Mato Grosso do Sul and Paraná, bordering the state of São Paulo, in the period of this study ${ }^{(22)}$.

The following sequence of procedures and standards of State Department of Agriculture and Food Supply of São Paulo (SAA-SP) were taken regarding the events reported in Table 4:

Table 4. FMD outbreaks registered in Mato Grosso do Sul (MS) and Parana (PR) States between 2005 and 2006

\begin{tabular}{cccc}
\hline Month/Year & State & $\mathbf{N}^{\mathbf{0}}$ Outbreaks & $\mathbf{N}^{\circ}$ Cases \\
\hline Oct/2005 & MS & 21 & 411 \\
Nov/2005 & MS & 7 & 89 \\
Dec/2005 & MS & 5 & 159 \\
Feb/2006 & PR & 6 & 20 \\
Apr/2006 & MS & 1 & 10 \\
\hline
\end{tabular}


- After notification of FMD occurrence in Mato Grosso do Sul, the entrance of animals susceptible to FMD, products, and by-products coming from the state were banned. SAA-SP regulated the entrance of animal products and by-products of Mato Grosso do Sul that were not from the FMD focus area;

After notification of FMD outbreaks confirmation in Paraná, the entrance of animals susceptible to FMD, products, and by-products coming from Paraná were banned. SAA / SP regulated the entrance of animal products and by-products of Paraná that were not from the FMD focus area;

- $\quad$ Beginning of vaccination against FMD in the stage of November (2005) was anticipated to October $25^{\text {th }}, 2005$;

Events with concentration of animals susceptible to FMD were banned. This resolution was revoked, considering the successful anticipation of the vaccination campaign against FMD, which had reached at least $85 \%$ of herds in São Paulo;

Technical Notes were described tracking procedures and inspection of properties that received animals from the states of Mato Grosso do Sul and Paraná in September and October 2005

New criteria were established for the entrance of animals susceptible to FMD, products, byproducts, and vegetables coming from Paraná, and amongst other laws, the entrance of animals for immediate slaughter was regulated;

New criteria were established for the entrance of animals susceptible to FMD, products, byproducts, and vegetables coming from Mato Grosso do Sul, and amongst other laws, the entrance of animals for immediate slaughter was regulated;

The entrance of animals susceptible to FMD, products, and by-products coming from areas in Mato Grosso do Sul considered out of risk by MAPA and through locations (entry points) listed in resolution was regulated;

The entrance of animals susceptible to FMD, products, and by-products coming from areas in Paraná considered out of risk by MAPA and through locations (entry points) listed in resolution was regulated;

The sanitary restrictions ruling in Paraná were suspended, considering that any risks of FMD outbreaks occurrences in 2005 and 2006 were dismissed;

- $\quad$ Considering the equivalent health condition of São Paulo and Mato Grosso do Sul regarding FMD, sanitary corridors were established and the entry of animal products subjected to heat treatment and animal by-products subjected to processing was authorized in Sao Paulo, as long as they came from Mato Grosso do Sul, sanitary corridors, and surveillance points existing on the borders of the States;

The ingress and egress of animals, fertile eggs, products, by-products and derivatives in São Paulo were authorized in compliance with the sanitary requirements demanded by law, as long as the states bordering São Paulo have the same health standard, and at that moment there was no health event in Brazil that could cause harm to animals.

The monitoring of absence of viral circulation in 2006, by making the properties sampling, prioritized those properties that received animals from Mato Grosso do Sul and Paraná. For these 
reasons, the surveillance and the issue of standards procedures in time by the OVS contributed decisively to contain the FMDV entrance in São Paulo.

The results presented in this paper, compared to the parameters, vaccination coverage, immune level, official control of animal transport, number of FMD outbreaks and years without illness, demonstrate that São Paulo proves FMD eradication. The state has a FMD eradication program that has been validated by OIE as FMD-free with vaccination, but to reach the FMD-free status without vaccination, the following information will be reviewed: 1) the Official Veterinary Service; 2) management of FMD; 3) surveillance of FMD; 4) diagnosis of FMD; 5) prevention of FMD; 6) emergency plan in cases of FMD.

The points analyzed in this study showed many aspects favorable to change the status. However, according to the Health Code for Terrestrial Animals ${ }^{(17)}$, Chapter 8.6, to create a FMD free zone without vaccination, measures should be adopted to prevent the entrance of the FMDV, taking into account the existing physical and geographical barriers.

The producers and industries of São Paulo maintain an intense trade of animals with neighboring states, either in the purchase of cattle for breeding, rearing, and fattening, or by the acquisition of animals for slaughtering industries. The raw material of bovine slaughtering in São Paulo is not obtained exclusively from local herds. Thus, it would be essential that the neighboring states and other areas with epidemiological link had similar level of control so that São Paulo would have a requirement of free area without vaccination validated, since blocking the sale of animals would currently be economically unfeasible.

\section{Conclusions}

This work proves that the measures, assessment strategies, and methods of FMD eradication program applied in São Paulo were effective for the intended purpose. Despite the analyzed data was shown to be favorable to change São Paulo status to FMD-free area without vaccination, other aspects must be verified, such as the structure of the state OVS, the level of control of the states with epidemiological link to São Paulo, and the commitment of the entire production chain regarding FDM.

\section{Acknowledgements}

We thank our colleagues Fernando G. Buchala and Lúcio O. Leite from Official Veterinary Services (OVS/SAA-SP), who provided insight and expertise that greatly assisted this research. This study was supported by OVS/SAA-SP.

\section{Conflict of interest statement}

The authors declare to have no conflict of interest. 


\section{References}

1. The Center for Food Security \& Public Health. Foot and Mouth Disease. 2014. Available from: $\langle$ http://www.cfsph.iastate.edu/Factsheets/pdfs/foot and mouth disease.pdf $>$. Last accessed November 05, 2016.

2. Oie. World Organization for Animal Health. World Assembly of Delegates of the OIE on 26 may 2015 resolution $\mathrm{n}^{\mathrm{o}} .17$ - recognition of the foot and mouth disease status of members. 2015a. Available from: <http://www.oie.int/fileadmin/Home/esp/Animal_Health_in_the_World/docs/pdf/2015_E_RESO_R17_FM D.pdf>. Last accessed October 05, 2015.

3. Iea. Instituto de Economia Agrícola. Secretaria de Agricultura e Abastecimento. Available from: < http://www.iea.sp.gov.br/out/LerTexto.php?codTexto=13656>. Last accessed Feb 01, 2017.

4. Torres, A. J.; Pino, F. A.; Francisco, V. L. F. S; Ângelo, J. A.; Maciel, E. L. F.; Drugowich, M. I.; Interliche, P. H.; Piedade, J. A.; Sousa, A. C.; Lorena Neto, B.; Caser, D. V. (Org.) Projeto LUPA 2007/08: censo agropecuário do estado de São Paulo. São Paulo: IEA: CATI: SAA, 2009. 381p.

5. São Paulo. Resolução SAA - 1, de 17 de janeiro de 2002. Estabelece as normas para execução dos projetos de controle e erradicação da anemia infecciosa equina, da febre aftosa e da raiva. Available from: $<$ http://www.OVS.sp.gov.br/www/legislacoes/popup.php?action=view\&idleg=93 >. Last accessed May 17, 2015 .

6. Brasil. Instrução Normativa 44, de 3 de outubro de 2007a. Diário Oficial da União, Brasília, DF, 03 out. 2007. Seção 1, p. 2.

7. Panaftosa. Centro Panamericano de Fiebre Aftosa. Programa Hemisférico de Erradicação da Febre Aftosa - plano de ação 2011-2020 (2011). <http://www.paho.org/panaftosa/index.php?option=com_content\&view= article\&id=55\&Itemid=281 $>$. Last accessed October 01, 2015.

8. São Paulo. Resolução SAA 74, de 27 de novembro de 2009. Altera a redação do Artigo 22 e seu parágrafo único e inclui os parágrafos $2^{\circ}$ e $3^{\circ}$ no mesmo artigo, altera a redação do Artigo 23, do Anexo II, da Resolução SAA - 1, de 17 de janeiro de 2002, que estabelece as normas para execução do projeto de controle e erradicação da febre aftosa, e revoga a Resolução SAA - 25, de 15 de abril de 2009. Diário Oficial do Estado de São Paulo, Poder Executivo, São Paulo, SP, 28 nov. 2009. Seção 1, p. 55.

9. São Paulo. Resolução SAA - 79, de 10 de dezembro de 2012. Implanta o GEDAVE - Sistema de Gestão de Defesa Animal e Vegetal e dá outras providências. Available from: <http://www.defesaagropecuaria.sp.gov.br/legislacoes/popup.php?action=info\&idleg=952>. Last accessed October 23, 2015.

10. Brasil. Ministério da Agricultura, Pecuária e Abastecimento. Monitoramento sorológico da vacinação contra a febre aftosa no rebanho bovino das unidades da Federação habilitadas para exportação à União Europeia. Brasília, 2008. Available from: 〈http://www3.servicos.ms.gov.br/iagro_ged/pdf/1439_GED.pdf〉. Last accessed July 15, 2015.

11. Brasil. Ministério da Agricultura, Pecuária e Abastecimento. Avaliação da imunidade populacional resultante das Campanhas de Vacinação Contra Febre Aftosa: relatório final, 2007b. Available from: <http://www.agricultura.gov.br/arq_editor/file/Aniamal/programa\%20nacional\%20sanidade\%20aftosa/avalia cao\%20da\%20imunidade.pdf>. Last accessed July 15, 2015.

12. Brasil. Ministério da Agricultura, Pecuária e Abastecimento. Monitoramento sorológico para avaliação da eficiência da vacinação contra a Febre Aftosa na Zona Livre: relatório final, 2011. Available from: <http://www.agricultura.gov.br/arq_editor/file/Relatorio avaliacao eficiencia vacinal ZL 2010 final 2.pdf 
>. Last accessed July 15, 2015.

13. São Paulo. Resolução Conjunta SAA/MAPA n ${ }^{\circ}$ 1, de 7 de março de 2006. Estabelece atribuições e nova composição do Grupo Especial de Atenção à Suspeita de Enfermidades Emergenciais - GEASE, para a adoção de medidas de defesa sanitária animal, na ocorrência de enfermidades emergenciais, no âmbito do Estado de São Paulo e dá outras providências. Diário Oficial do Estado de São Paulo, Poder Executivo, São Paulo, SP, 09 mar. 2006. Seção 1, p. 10.

14. Panaftosa. Centro Panamericano de Fiebre Aftosa. SIVCONT - Sistema Continental de Vigilância Epidemiológica, 2015a. Available from: <http://www.paho.org/panaftosa/index.php?option=com content\& view=article\&id=138\&Itemid=234>. Last accessed October 01, 2015.

15. Panaftosa. Centro Panamericano de Fiebre Aftosa. Instrutivo de uso NCPanaftosa - prova triagem bovino Kit diagnóstico para detecção de anticorpos contra proteínas não capsidais do vírus da febre aftosa, 2015 b.

Available

from:

$<$ http://www.paho.org/panaftosa/index.php?option=com_content\&view=article\&id=150\& $\quad$ Itemid=235>. Last accessed August 10, 2015.

16. Panaftosa. Centro Panamericano de Fiebre Aftosa. Instrutivo de uso NCPanaftosa - prova confirmatória bovino kit diagnóstico para detecção de anticorpos contra proteínas não capsidais do vírus da febre aftosa, 2015c. Available from: <http://www.paho.org/panaftosa/index.php?option=com_content\&view= article\&id=150\&Itemid=235> . Last accessed August 10, 2015.

17. Oie. World Organization for Animal Health. Terrestrial Manual. 2013. Available from: <http://www.oie.int/es/normas-internacionales/codigo-terrestre/acceso-en-linea/>. Last accessed October 25, 2015.

18. Brasil. Instrução Normativa 50, de 24 de setembro de 2013. Altera a lista de doenças passíveis da aplicação de medidas de defesa sanitária animal, previstas no art. 61 do Regulamento do Serviço de Defesa Sanitária Animal, publicado pelo Decreto $\mathrm{n}^{\circ}$ 24.548, de 3 de julho de 1934, na forma do Anexo à presente Instrução Normativa. Available from: $\langle$ http://sistemasweb.agricultura.gov.br/sislegis/action/detalhaAto.do?method= consultarLegislacaoFederal $>$. Last accessed July 15, 2015.

19. Brasil. Ministério da Agricultura, Pecuária e Abastecimento. Plano de Ação para a Febre Aftosa. 2009. Available from: <http://www.agricultura.gov.br/arq_editor/file/Aniamal/programa\%20nacional\%20sanidade\%20 aftosa/MIOLO plano acao.pdf>. Last accessed August 20, 2015.

20. Panaftosa. Manual de procedimentos para a atenção às ocorrências de febre aftosa e outras enfermidades vesiculares. Projeto BID/ PANAFTOSA - OPAS/OMS para os países do MERCOSUL Ampliado. Rio de Janeiro: PANAFTOSA - OPAS/OMS, 2007. 144p.

21. Bergmann, I.E., Marilat V. \& Falczuk A.J. Evolving perception on the benefits of vaccination as a foot and mouth disease control policy: contributions of South America. Expert Rev Vaccine, 2005. 4(6):903-913.

22. OIE. World Organization for Animal Health. WAHID interface. 2015b. Available from: <http://web.oie.int/wahis/public.php>. Last accessed October 05, 2015. 